\title{
Analysis of Operational Efficiency of the Proposed Propulsion Systems for Selected Large RoPax Vessel
}

\section{Analiza radne učinkovitosti predloženih porivnih sustava za odabrani veliki RoPax brod}

\author{
Piotr Kamil Korlak \\ Maritime University of Szczecin \\ Doctoral School \\ Poland \\ E-mail: 27901@s.am.szczecin.pl
}

\section{Summary}

This paper presents the characteristics of ferry shipping with particular emphasis on large RoPax vessels operating in the Baltic Sea. A critical review of main propulsion system used on large RoPax ferries has been done. Optimal propeller parameters and required brake power have been estimated on the basis of total resistance of bare hull and appendages approximated according to Holtrop-Mennen method. Main engines and generating sets have been selected for minimized fuel consumption approximated with quadratic regression. Operational parameters and costs of analysed large RoPax main propulsion systems have been compared.

Sažetak

U ovome radu prikazane su karakteristike trajektnog prijevoza s posebnim osvrtom na velike RoPax brodove koji plove u Baltiku. Dan je kritički pregled glavnoga porivnog sustava koji se koristi na velikim RoPax trajektima. Procijenjeni su optimalni parametri propelera i potrebna efektivna snaga kočenja na temelju ukupnog otpora samoga trupa i dodataka što je približno izračunato uporabom Holtrop-Mennen metode. Glavni motori i generatori odabrani su za minimalnu potrošnju goriva procijenjenu kvadratnom regresijom. Uspoređeni su radni parametri i troškovi analiziranih velikih RoPax glavnih porivnih sustava.

\author{
DOI 10.17818/NM/2021/3.7 \\ UDK 629.541.2/.4 \\ Review / Pregledni rad \\ Paper accepted / Rukopis primljen: 18. 1.2021.
}

\author{
KEY WORDS \\ Marine propulsion \\ CODAD \\ CODEL \\ CODED \\ Azipod
}

KLJUČNE RIJEČI
brodski pogon
CODAD
CODEL
CODED
Azipod

\section{INTRODUCTION / Uvod}

Ferry shipping has been an extremely important component of international transport system for decades. Due to their functions, in particular complementary role in respect of the existing routes of land transport and shore outline, ferry routes are largely limited to sea basin with a highly fragmented shoreline [1]. The Baltic Sea is a leading market for ferry services where approximately $17 \%$ of international ferry fleet is used [2]. These specific conditions prejudge local advantage of ferry shipping both over land transport and container shipping which is the most popular on a global scale. Implementation of horizontal loading (Roll-On/Roll-Off) of passenger cars and trucks, semi-trailers, wagons and roll-trailers, etc. on board has greatly contributed to facilitation of loading and unloading of ferries while indirectly leading to the decrease of the transport distance, cost and time as well as to the elimination of timeconsuming container handling.

The most popular vessels in contemporary ferry shipping are RoPax (Roll-On/Roll-Off - Passenger) vessels with separate decks for passengers and rolling cargo. The first RoPax ferries were constructed as a result of conversion of the existing RoRo ferries with an expansion by a passenger section, whereas the following models were designed bottom-up by adjusting vessel specification to the characteristics of a given route [3]. International trans-Baltic routes are currently dominated by large RoPax vessels with a gross tonnage above 40,000 [2].

Nowadays the development of propulsion systems is aimed primarily at energy efficiency and reduction in emissions of harmful substances. Chapter 4 of the MARPOL Annex VI, put into effect in July 2011, obliged shipowners to use technical solutions to reduce carbon dioxide (CO2) emissions. All vessels over 400 GT built as from January 2013 are subject to the Energy Efficiency Design Index (EEDI). The standard puts a cap on the amount of $\mathrm{CO} 2$ allowed per unit of transport work. Until 2025 , ships are required to achieve a 30-percent reduction in their $\mathrm{CO} 2$ emissions compared with the average emissions of ships built between 1999 and 2009. The EEDI value calculated in accordance with the procedure shown in Figure 1 must be less than or equal to the value required for the type and size of vessel [4]. In addition, according to the findings of the 75th session of the Marine Environment Protection Committee (MEPC), from 2023 all in-service vessels are planned to be subject to minimum energy efficiency standards, as defined by the EEDI-equivalent Energy Efficiency Existing Ship Index (EEXI) [5]. 


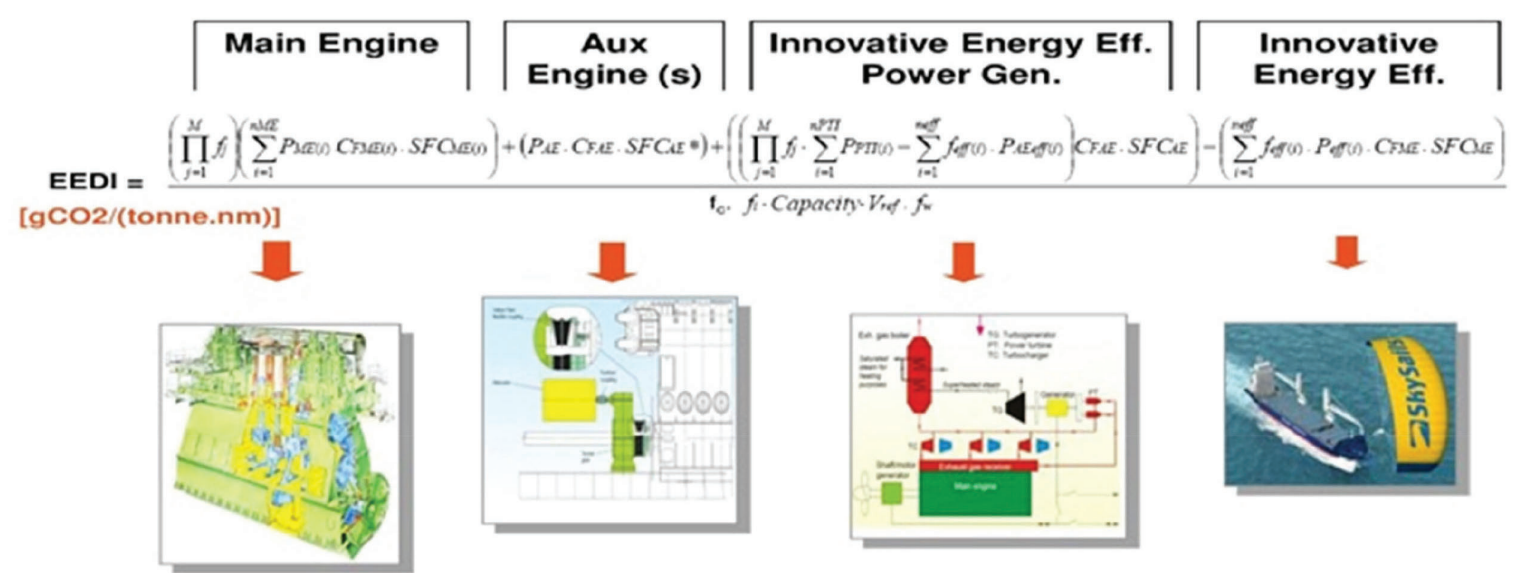

Boilers are excluded from EEDI

Figure 1 Energy Efficiency Design Index (EEDI)

Source: Bazari, Z. [4]

Slika 1. Indeks dizajna energetske učinkovitosti

However, $\mathrm{CO}_{2}$ is not the only substance restricted by MARPOL Annex VI. The existing IMO limits on nitrogen oxide $\mathrm{NO}_{\mathrm{x}}$ emissions, and fuel sulphur content, are shown in Figure 2. Continually decreasing and territorially expanding restrictions also apply to nitrogen oxides $\mathrm{NO}_{x}$ and sulphur oxides $\mathrm{SO}_{\mathrm{x}}$. They are strictly defined in the current IMO Tier II and Tier III standards. Tier II is global, while the range of the more restrictive Tier III is currently limited to the Baltic and North Sea, and the parts of North American coastal waters. The sulphur content reduction to $0.1 \%$, met by e.g. Marine Gas Oil (MGO) and Liquified Natural Gas (LNG), has also applied in the territorial seas of the European Union Member States [6].

Compliance with MARPOL Annex VI regulations is an important reason why propulsion systems are still being modernised. One of the basic issues having financial consequences is the operational efficiency of the propulsion system. In the design of RoPax vessels, the current priority is the common use of combined propulsion systems [3, 7].

The aim of this paper is to compare the operational efficiency of different main propulsion systems for large RoPax vessels, using certain energy and economic indicators calculated relative to those of the traditional CODAD main propulsion system.

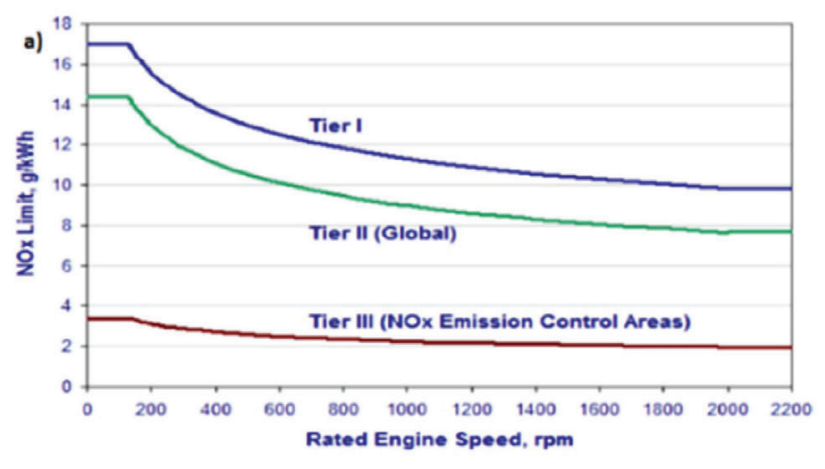

Calculations of resistance based on geometrical data for the m/f Finnstar (45,923 GT) hull were performed by the HoltropMennen method, due to the ease of taking account of differences in resistance caused by appendages. Performance parameters of engines and generating sets were approximated by quadratic regression using data provided by the manufacturers.

\section{PROPULSION SYSTEMS OF THE LARGE ROPAX FERRIES / Porivni sustavi velikih RoPax trajekata}

All European large RoPax ferries (i.e. over 40,000 GT), including both those in operation and those on order books, are still equipped with one of the following propulsion systems [8]:

- Traditional, diesel-mechanical CODAD (Combined Diesel and Diesel);

- Diesel-electric CODEL (Combined Diesel-Electric);

In each of the aforementioned cases, medium-speed engines are used. Despite having lower power and efficiency than low-speed engines, these offer significantly lower height, which is particularly important with regard to the need to reduce the engine room height and improve stability.

The CODAD propulsion system has been associated with RoPax vessels since the 1960s, when the first such units were

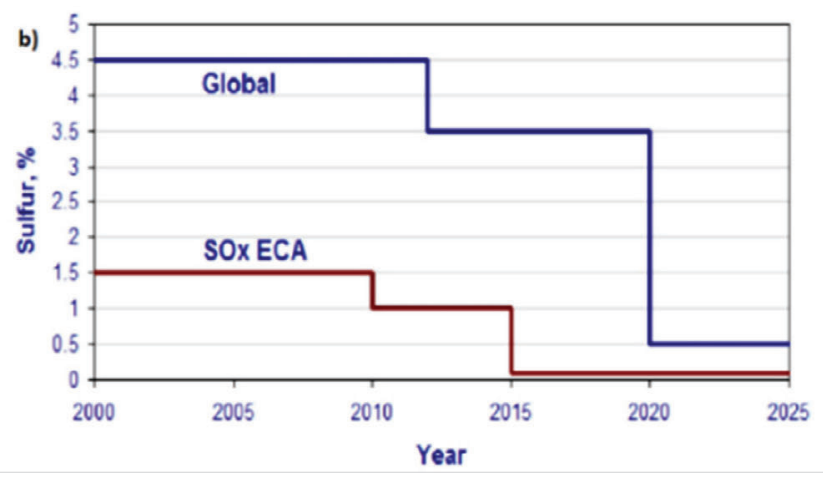

Figure 2 MARPOL Annex VI limits of: a) $\mathrm{NO}_{x}$ emission, b) fuel sulphur content Slika 2. MARPOL Aneks VI ograničenja: a) NO emisije, b) sadržaja sumpora u gorivu Source: Clausen, N.B. (2015) [6] 


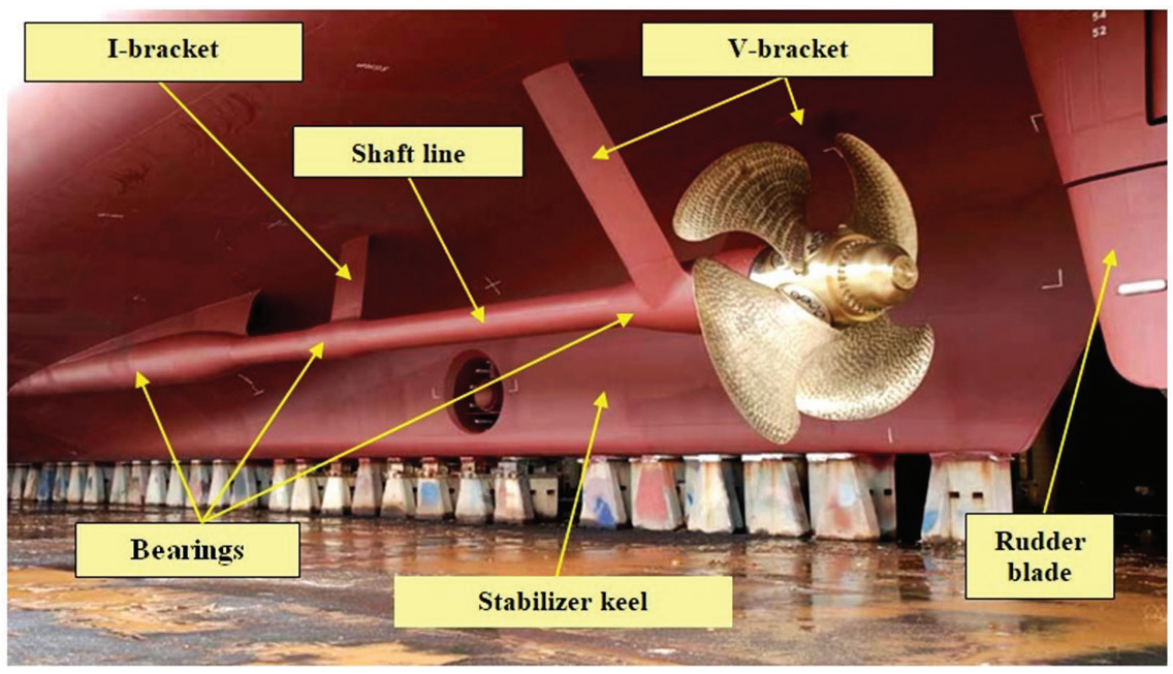

Figure 3 Appendages of the hull equipped with CODAD Slika 3. Dodatci na trupu opremljenom CODAD-om

Source: Own study on basis [10]

brought into service, and is still the predominant solution. In the most common variant, each pair of main engines (of the same type and with the same or different power) drives one controllable pitch propeller shaft through a reduction gear. Behind the controllable pitch propeller there are a rudder blade and open shaft lines outside the hull separated by a stabilizer keel (Figure 3) [3, 9].

The use of four main engines allows their load to be adjusted in a flexible manner to the required brake power. As a result, engine run time can be maximised within a load range similar to the optimum range [3]. If brake power demand is reduced, engines 3 and 4 , connected to the reduction gear with a long shaft, are shut down, so that engines 1 and 2 (Figure 4) may be properly loaded and the entire system avoids inefficient operation at low load range. CODAD is mainly characterised by $[3,11]$ :

- Moderate investment costs;

- Adoption to longer (e.g. trans-Baltic) shipping routes during which operation under contract load is predominant;

- Difficulty in maintaining the main engines within their optimum load range - at partial loads specific fuel consumption increases;

- Necessity to place the entire engine room in aft part of the hull below waterline.

The CODEL propulsion system (Figure 5 ) is implemented in e.g. two existing large RoPax vessels (m/f Megastar 49,000 GT and $\mathrm{m} / \mathrm{f}$ Viking Grace 59,565 GT) serving short routes between ports in the Gulf of Finland, where, due to the route characteristics, operation under contract load is restricted to approximately $20 \%$ of shipping time $[7,13]$. Moreover, one of Tallink's large RoPax ferries currently under construction ( $\mathrm{m} / \mathrm{f}$ MyStar 49,000 GT) is also to be equipped with CODEL [17]. In this system, diesel generating sets with medium-speed engines powering synchronous generators produce electrical energy supplying two synchronous motors of a fixed pitch propeller system with the use of transformers and frequency converters. In comparison with CODAD, the CODEL system is characterised by [14]:

- Maintaining optimum load of combustion engines regardless of the vessel's speed;

- Easiness of automation;

- Application of more efficient fixed pitch propellers instead of controllable pitch propellers;

- No mechanical connections between the diesel generating sets and the synchronous motors, which allows engine room to be relocated outside of the standard area in aft part of the hull to a suitable place where it is possible e.g. to increase cargo space or reduce the hull's dimensions (and the required brake power) while maintaining current brake power;

Reduction of vibrations on board to considerably increase crew and passenger comfort;

Significant losses (by about $8 \div 9 \%$ ) in electrical energy transmission from generators to the propeller motor; Installation in a hull of the same form and exterior design.

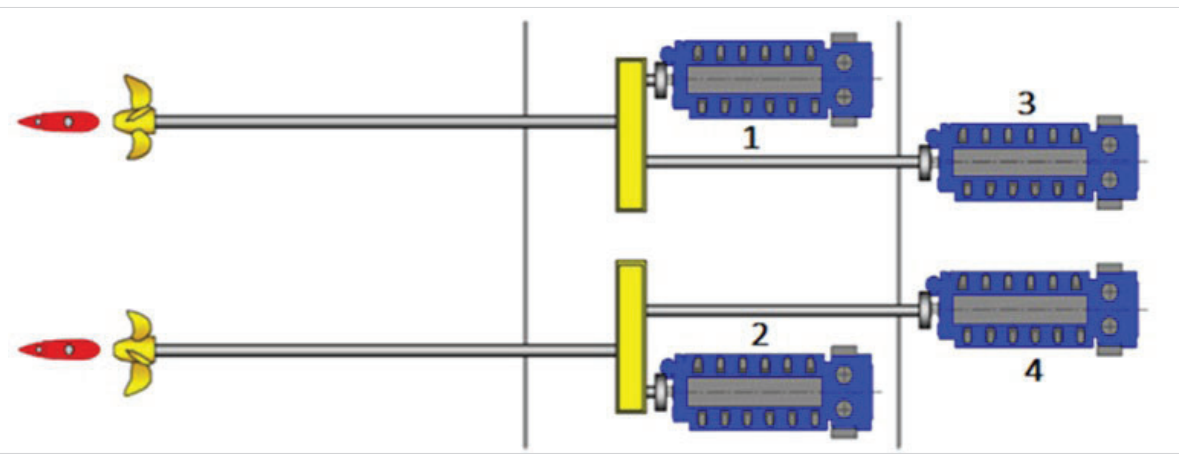

Figure 4 CODAD propulsion system: medium speed engines are marked with numbers 1, 2, 3, 4 Slika 4. CODAD porivni sustav: srednje-hodni motori označeni su brojevima 1, 2, 3, 4 


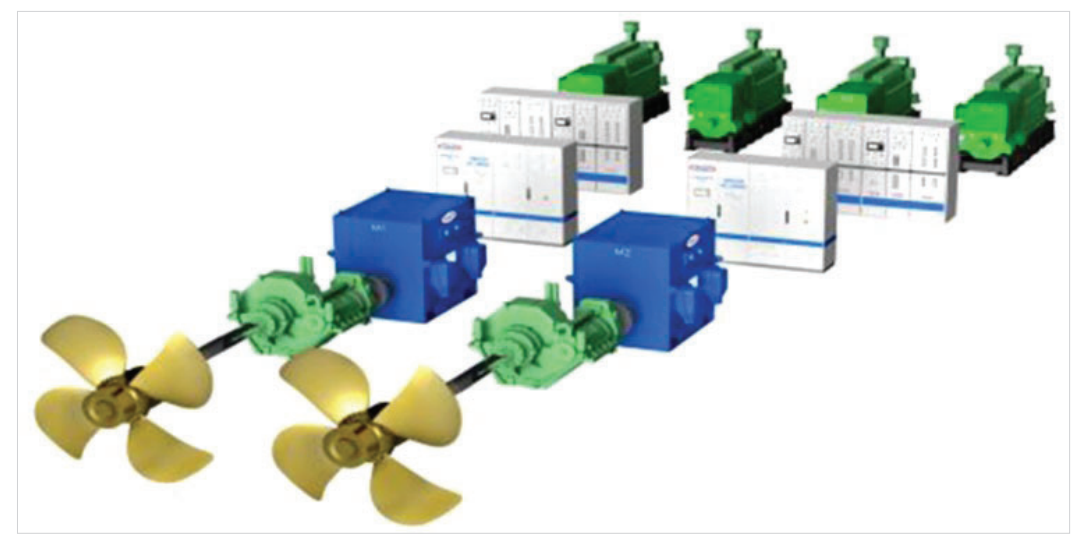

Figure 5 CODEL propulsion system Slika 5. CODEL porivni sustav

Source: Łosiewicz, Z. and Łukasik, Z. [14]

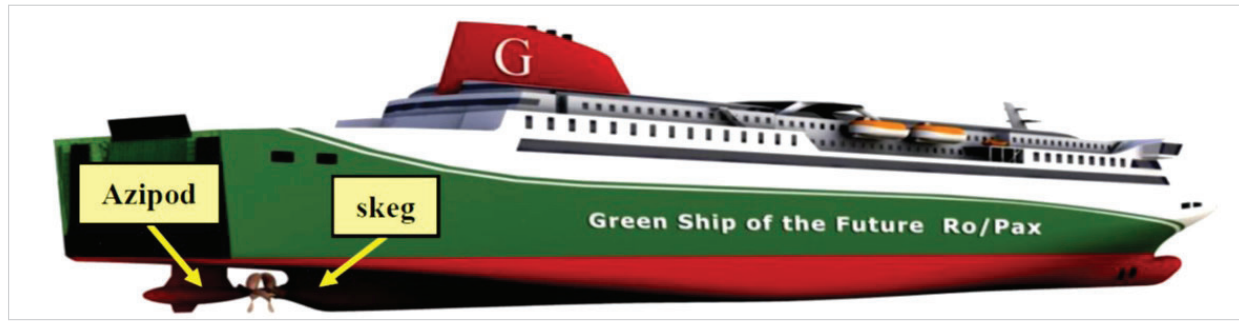

Figure 6 Appendages of the RoPax equipped with CODED-CRP

Source: Own study on basis [15]

Slika 6. Dodatci na RoPax brodu opremljenom CODED-CRP

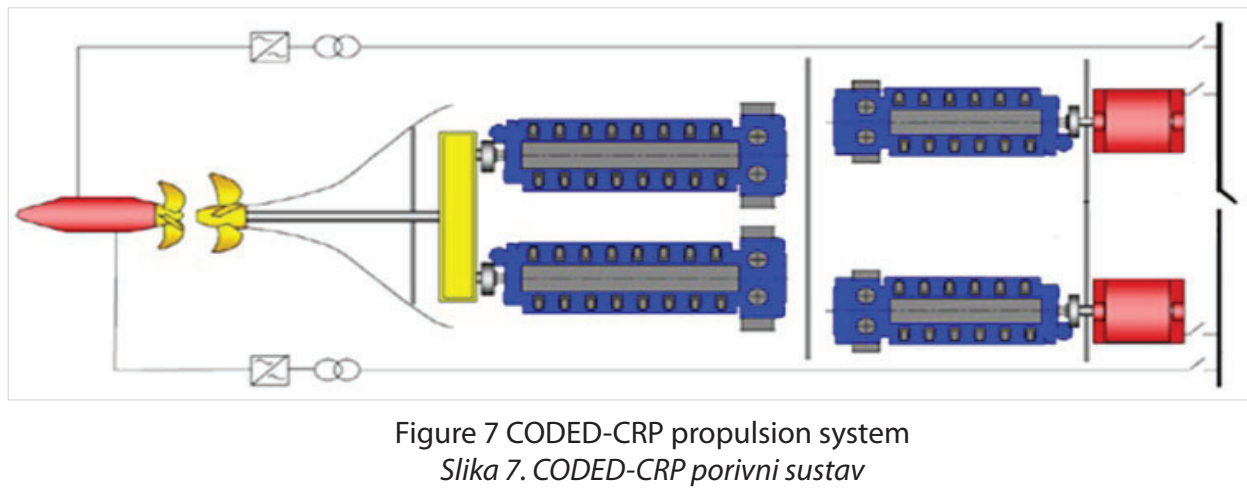

Source: Levander, O. [7]

In this paper the CODED-CRP (Combined Diesel-Electric and Diesel-Mechanical - Contra-Rotating Propeller) system is also considered. Although this system has not been used in large RoPax ferries, it has been successfully implemented in smaller twin Coastal Ferry vessels ( $\mathrm{m} / \mathrm{f}$ Akashia and Hamanasu, $16,810 \mathrm{GT}$ ). An illustration of a RoPax equipped with CODEDCRP is shown in Figure 6.

In the CODED-CRP hybrid propulsion system, a pair of medium-speed engines drives a controllable pitch propeller through a reduction gear. In its axis is a podded azimuth thruster (Azipod) with a contra-rotating fixed pitch propeller, which utilises some of the energy of the circular movement of water generated by the controllable pitch propeller. Electrical energy for propulsion purposes is generated by diesel generating sets with medium-speed engines powering the Azipod low-speed synchronous motor through transformers and frequency converters [3]. This system consists of a dieselmechanical part with a design and principle of operation fully equivalent to those of CODAD, and a diesel-electric part with a design and principle of operation corresponding to a CODEL variant used in Azipod-equipped cruise ferries. Both sections may be operated simultaneously or separately as required. Moreover, the hull of a vessel with such a propulsion system has a form similar to the hull of single-propeller vessels. An exemplary CODED-CRP configuration is shown in Figure 7.

In comparison to both previously discussed propulsion systems, CODED-CRP is characterised by very high investment costs and advantages mentioned in Table 1 [8]: 
Table 1 Advantages of the CODED-CRP propulsion system

Tablica 1. Prednosti CODED-CRP porivnog sustava

\begin{tabular}{|l|l|}
\hline \multicolumn{1}{|c|}{ Economic } & \multicolumn{1}{c}{ Technical } \\
\hline Less fuel consumption per hour & Increased total propulsion system efficiency \\
\hline Less installed power & Less required service power \\
\hline $\begin{array}{l}\text { Smaller repair costs and longer overhaul periods } \\
\text { No need for use of towing services in ports }\end{array}$ & $\begin{array}{l}\text { Less emission of pollutants from engines operating in the near } \\
\text { optimal load range }\end{array}$ \\
\hline $\begin{array}{l}\text { Limited manoeuvring time in ports } \\
\text { parts of propulsion system to convinient place in hull }\end{array}$ & Increased reliability and lifetime \\
\hline No rudder blades & Excellent manoeuvrability \\
\hline
\end{tabular}

Source: Korlak, P. [8]

The basic type of RoPax vessel propulsion system and a reference for other system is the CODAD. Alternative design solutions may be introduced with regard to the characteristics of a given route, e.g. low share of shipping at contractual speed in total sailing time or the need to increase cargo space at limited hull dimensions.

\section{RESISTANCE CALCULATIONS AND SELECTION OF THE PROPULSION SYSTEM ELEMENTS / Izračuni otpora i odabir elemenata porivnog sustava}

The values of effective power and parameters of the propulsion system were estimated using the Holtrop-Mennen method for the three above-mentioned variants. The total resistance is considered to be a sum of the following components [16, 17]:

$$
\mathrm{R}_{\mathrm{T}}=\mathrm{R}_{\mathrm{V}_{\mathrm{BH}}}+\mathrm{R}_{\mathrm{V}_{\mathrm{APP}}}+\mathrm{R}_{\mathrm{W}}+\mathrm{R}_{\mathrm{B}}+\mathrm{R}_{\mathrm{S}}+\mathrm{R}_{\mathrm{A}}
$$

Viscous resistance of bare hull and appendages in (1) as a sum of their frictional and viscous pressure resistance were determined through use a form factor $[16,17]$ :

and:

$$
\mathrm{R}_{\mathrm{V}_{\mathrm{BH}}}=\mathrm{R}_{\mathrm{F}_{\mathrm{BF}}} \cdot\left(1+\mathrm{k}_{\mathrm{BH}}\right)
$$

$$
\mathrm{R}_{\mathrm{V}_{\mathrm{APP}}}=\mathrm{R}_{\mathrm{F}_{\mathrm{APP}}} \cdot\left(1+\mathrm{k}_{\mathrm{APP}}\right)
$$

$R_{B}$ and $R_{S}$ components shown in (1) were omitted in calculations as they represent on average only $(0.02 \div 0.025) \%$ of total resistance [17], thus:

$$
\mathrm{R}_{\mathrm{T}} \cong \mathrm{R}_{\mathrm{V}_{\mathrm{BH}}}+\mathrm{R}_{\mathrm{V}_{\mathrm{APP}}}+\mathrm{R}_{\mathrm{W}}+\mathrm{R}_{\mathrm{A}}
$$

where:

$\mathrm{R}_{\mathrm{T}}, \mathrm{kN}$ - Total resistance

$\mathrm{R}_{\mathrm{T}_{\mathrm{BH}}} \mathrm{kN}$ - Viscous pressure resistance of bare hull

$\left(1+\mathrm{k}_{\mathrm{BH}}\right)$ - Form factor of bare hull

$\mathrm{R}_{\mathrm{F}_{\mathrm{BH}}} \mathrm{kN}$ - Frictional resistance of bare hull according to the ITTC-57 formula

$\mathrm{R}_{\mathrm{V}_{\mathrm{APP}}}, \mathrm{kN}$ - Viscous pressure resistance of the appendages

$\left(1+k_{A P P}\right)$ - Form factor of the appendages

$\mathrm{R}_{\mathrm{F}_{\mathrm{APP}}}, \mathrm{kN}$ - Frictional resistance of the appendages according to the ITTC-57 formula

$\mathrm{R}_{\mathrm{W}}, \mathrm{kN}$ - Wave resistance

$\mathrm{R}_{\mathrm{A}}, \mathrm{kN}$ - Model-vessel correlation resistance (incl. such effects as hull roughness of $k_{s}=150 \mu \mathrm{m}$ and air drag in conditions of 2 in the Beaufort scale)

$\mathrm{R}_{\mathrm{B}}, \mathrm{kN}$ - Additional pressure resistance of bulbous bow near the water surface

$\mathrm{R}_{\mathrm{S}}$, kN - Additional pressure resistance due to transom immersion

The estimation was based on actual parameters of the hull of $\mathrm{m} / \mathrm{f}$ Finnstar ferry equipped with the CODAD provided in Table 2. External and longitudinal section view of $\mathrm{m} / \mathrm{f}$ Finnstar are presented in Figure 8.

Estimates were made of the total resistance of the bare hull, which is the same for all of the analysed propulsion system

Table 2 Hull parameters of the $\mathrm{m} / \mathrm{f}$ Finnstar Tablica 2. Parametri trupa motornog trajekta Finnstar

\begin{tabular}{|c|l|c|c|c|}
\hline No. & \multicolumn{1}{|c|}{ Parameter } & Symbol & Unit & Value \\
\hline 1. & Length overall & $\mathrm{L}_{\mathrm{OA}}$ & $\mathrm{m}$ & 218.8 \\
\hline 2. & Length between perpendiculars & $\mathrm{L}_{\mathrm{PP}}$ & $\mathrm{m}$ & 199.9 \\
\hline 3. & Waterline length & $\mathrm{L}_{\mathrm{WL}}$ & $\mathrm{m}$ & 211.95 \\
\hline 4. & Beam & $\mathrm{B}$ & $\mathrm{m}$ & 30.5 \\
\hline 5. & Draught & $\mathrm{T}$ & $\mathrm{m}$ & 7.1 \\
\hline 6. & Gross tonnage & $\mathrm{GT}$ & - & 45,923 \\
\hline 7. & Deadweight tonnage & $\mathrm{DWT}$ & $\mathrm{t}$ & 9,653 \\
\hline 8. & Lightweight tonnage & $\mathrm{LT}$ & $\mathrm{t}$ & 17,000 \\
\hline 9. & Displacement & $\mathrm{C}_{\mathrm{B}}$ & $\mathrm{t}$ & 26,653 \\
\hline 10. & Block coefficient & $\mathrm{C}_{\mathrm{P}}$ & - & 0.5662 \\
\hline 11. & Prismatic coefficient & $\mathrm{V}_{\mathrm{s}}$ & $\mathrm{kn}$ & 0.5876 \\
\hline 12. & Service speed & & & 25 \\
\hline
\end{tabular}

Source: DNV - GL [12] 


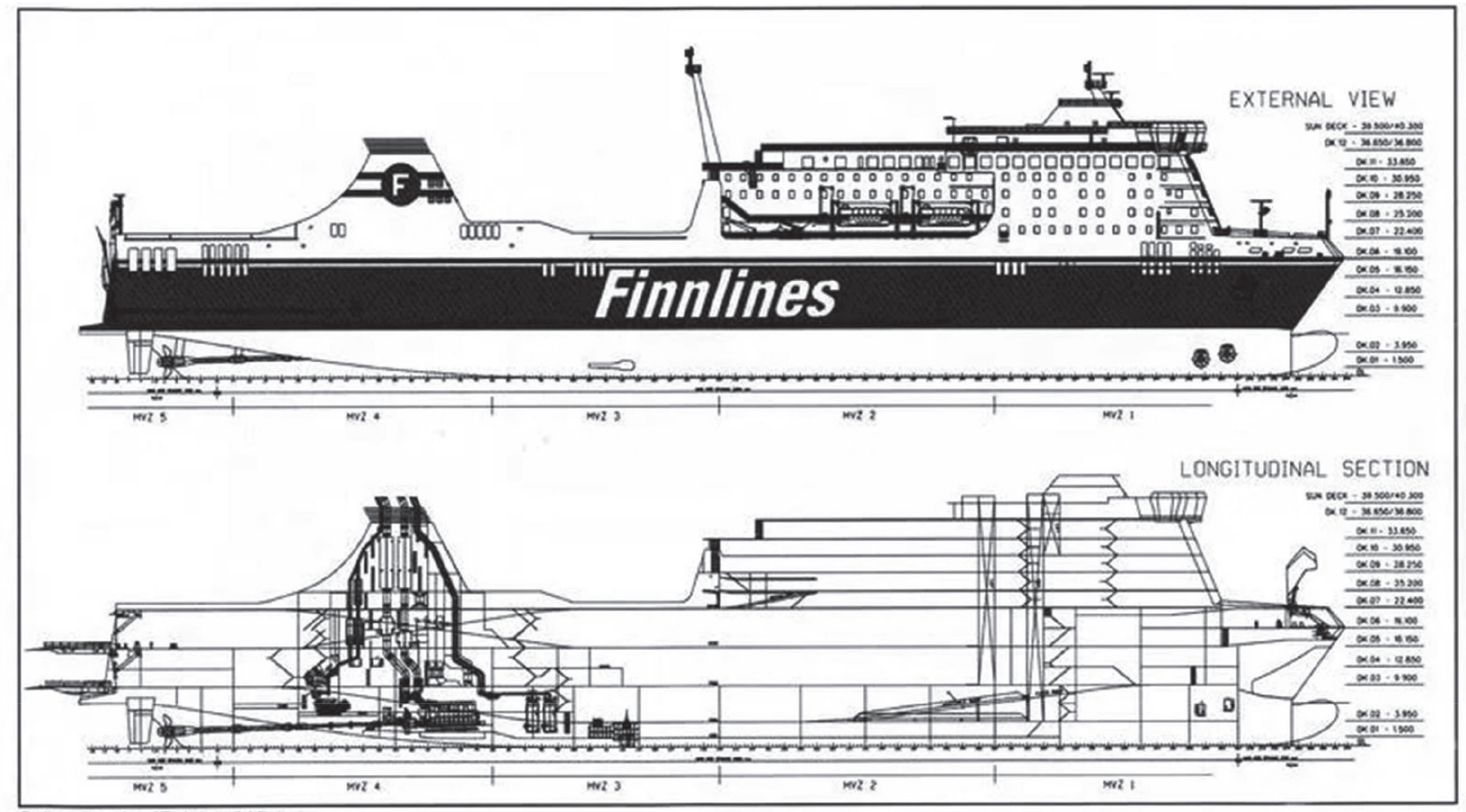

Seitenriss der "Finnstar"-Klasse.

Figure 8 External and longitudinal view of $m / f$ Finnstar

(Zeichnung: Fincantieri)

Source: Fincantieri [18] Slika 8. Vanjski i uzdužni presjek $m / t$ Finnstar

designs, and the resistances of appendages protruding outside the hull, required for a given propulsion system. These two components were added to obtain the value of the vessel's total resistance. The most important values related to the resistance and effective power of a potential vessel with any of the analysed propulsion systems are given in Table 3. Furthermore, values corresponding to sea trial conditions were increased by a sea margin of $15 \%$ and an engine margin of $10 \%$ to obtain service and maximum values in nominal conditions.
Appendages viscous resistance of a vessel equipped with CODED-CRP is lower by $38.4 \%$ (equivalent to $39.68 \mathrm{kN}$ ) than the values for CODAD and CODEL, resulting from a smaller wetted surface area and lower form factor of appendages (Table 3), leading to a lower total resistance and effective power for the same service speed under identical sailing conditions. A comparison of appendages viscous resistance is presented in Figure 9.

Table 3 Results of the resistance calculations Tablica 3. Rezultati izračuna otpora

\begin{tabular}{|c|c|c|c|c|c|}
\hline \multicolumn{6}{|c|}{ Rezultc } \\
\hline & & & & CODAD \& CODEL & CODED-CRP \\
\hline No. & Parameter & Symbol & Unit & \multicolumn{2}{|c|}{ Value } \\
\hline 1. & Bare hull wetted surface area & $\mathrm{S}_{\mathrm{BH}}$ & $\mathrm{m}^{2}$ & \multicolumn{2}{|c|}{$6,353.83$} \\
\hline 2. & Bare hull total resistance & $\mathrm{R}_{\mathrm{T}_{\mathrm{BH}}}$ & $\mathrm{kN}$ & \multicolumn{2}{|c|}{$1,392.91$} \\
\hline 3. & Bare hull form factor & $\left(1+k_{1}\right)$ & - & \multicolumn{2}{|c|}{1.0916} \\
\hline 4. & Appendages wetted surface area & $\mathrm{S}_{\mathrm{APP}}$ & $\mathrm{m}^{2}$ & $\begin{array}{c}476.54 \\
100 \%\end{array}$ & $\begin{array}{c}338.38 \\
71 \%\end{array}$ \\
\hline 5. & Appendages form factor & $\left(1+k_{2}\right)$ & - & $\begin{array}{c}1.85 \\
100 \%\end{array}$ & $\begin{array}{l}1.61 \\
87 \%\end{array}$ \\
\hline 6. & Appendages viscous resistance & $\mathrm{R}_{\mathrm{V}_{\mathrm{APP}}}$ & $\mathrm{kN}$ & $\begin{array}{l}103.4 \\
100 \%\end{array}$ & $\begin{array}{l}63.72 \\
61.6 \%\end{array}$ \\
\hline 7. & $\begin{array}{l}\text { Total resistance for service speed } \\
\text { (sea trials conditions) }\end{array}$ & $\mathrm{R}_{\mathrm{T}_{\mathrm{st}}}$ & $\mathrm{kN}$ & $\begin{array}{c}1,496.31 \\
100 \%\end{array}$ & $\begin{array}{l}1,456.63 \\
97.3 \%\end{array}$ \\
\hline 8. & $\begin{array}{l}\text { Total resistance for service speed } \\
\text { (nominal conditions) }\end{array}$ & $\mathrm{R}_{\mathrm{T}_{\mathrm{s}}}$ & $\mathrm{kN}$ & $1,724.62$ & $1,674.8$ \\
\hline 9. & $\begin{array}{l}\text { Total resistance for maximum speed } \\
\text { (nominal conditions) }\end{array}$ & $\mathrm{R}_{\mathrm{T}_{\text {max }}}$ & $\mathrm{kN}$ & $1,845.15$ & $1,796.22$ \\
\hline 10. & $\begin{array}{l}\text { Effective power for service speed } \\
\text { (nominal conditions) }\end{array}$ & $\mathrm{P}_{\mathrm{E}_{\mathrm{s}}}$ & kW & $22,128.92$ & $21,542.1$ \\
\hline 11. & $\begin{array}{l}\text { Effective power for maximum speed } \\
\text { (nominal conditions) }\end{array}$ & $\mathrm{P}_{\mathrm{E}_{\max }}$ & kW & $24,587.7$ & $23,925.67$ \\
\hline
\end{tabular}




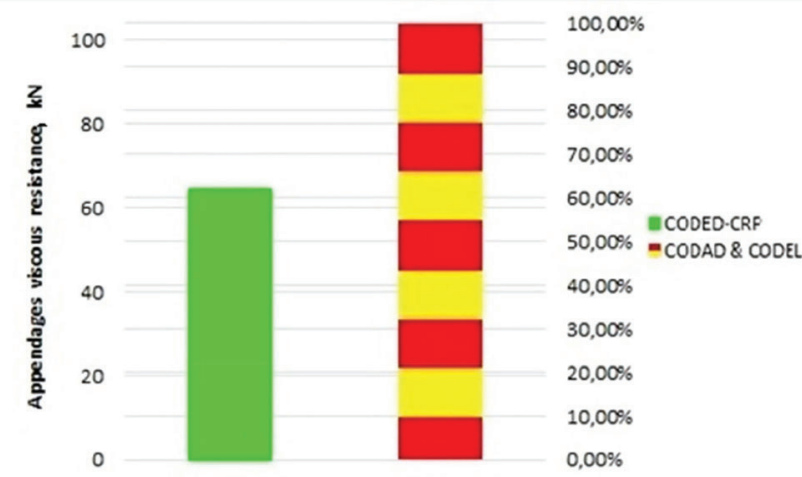

Figure 9 Appendages viscous resistance compared to CODAD \& CODEL. Value corresponding to CODAD \& CODEL is a $100 \%$ reference point

Slika 9. Viskozni otpor dodataka u usporedbi s CODAD i CODEL. Vrijednost koja odgovara CODAD i CODEL je 100\% referentna točka Source: Own study

Using the estimated values of effective power, optimum geometric and operating parameters of propellers as well as values of efficiency of propulsion systems with components and the required brake power were calculated according to the following formulae $[16,19]$ :

CODAD propulsion system:

$$
\mathrm{P}_{\mathrm{B}_{\text {CODAD }}}=\frac{\mathrm{P}_{\mathrm{E}_{\text {CODAD }}}}{\eta_{\mathrm{T}_{\text {CODAD }}}}=\frac{\mathrm{P}_{\mathrm{E}_{\text {CODAD }}}}{\eta_{\mathrm{H}} \cdot \eta_{\mathrm{O}} \cdot \eta_{\mathrm{R}} \cdot \eta_{\mathrm{S}} \cdot \eta_{\mathrm{G}}}
$$

where:

$\mathrm{P}_{\mathrm{B}}, \mathrm{kW}$ - Brake power

$\mathrm{P}_{\mathrm{E}}, \mathrm{kW}$ - Effective power

$\eta_{\mathrm{T}}$ - Total efficiency of propulsion system

$\eta_{\mathrm{H}}$ - Hull efficiency

$\eta_{\mathrm{O}}$ - Open water propeller efficiency

$\eta_{R}$ - Propeller rotative efficiency

$\eta_{\mathrm{S}}$ - Shaft line efficiency

$\eta_{G}-$ Gearbox efficiency

Efficiencies of the components of CODAD propulsion system are shown in Figure 10.

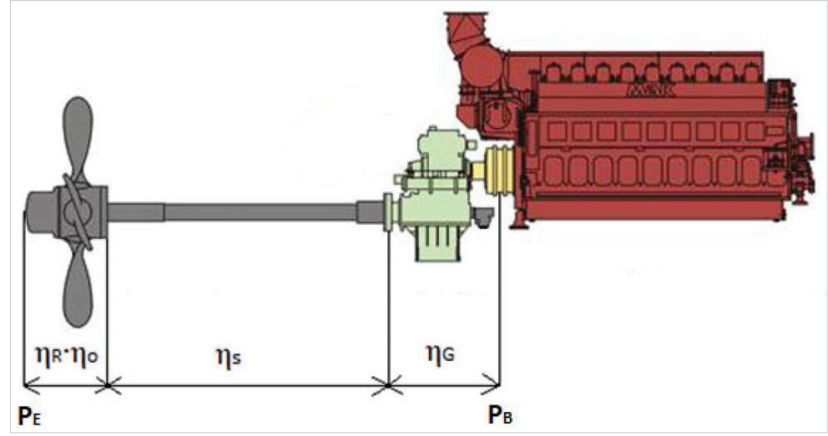

Figure 10 Efficiencies of the CODAD propulsion system components

Slika 10. Učinkovitosti komponenti CODAD porivnog sustava Source: Leduc, M. [20]

CODEL propulsion system:

where:

$$
\mathrm{P}_{\mathrm{B}_{\text {CODEL }}}=\frac{\mathrm{P}_{\mathrm{E}_{\text {CODEL }}}}{\eta_{\mathrm{T}_{\text {CODEL }}}}=\frac{\mathrm{P}_{\mathrm{E}_{\text {CODEL }}}}{\eta_{\mathrm{H}} \cdot \eta_{\mathrm{O}} \cdot \eta_{\mathrm{R}} \cdot \eta_{\mathrm{Gen}} \cdot \eta_{\text {Ele }}}
$$

$\eta_{\text {Gen - Generator efficiency }}$

$\eta_{\text {Ele }}$ - Efficiency of electrical energy transmission from generator to motor
Efficiencies of the components of CODEL propulsion system are shown in Figure 11

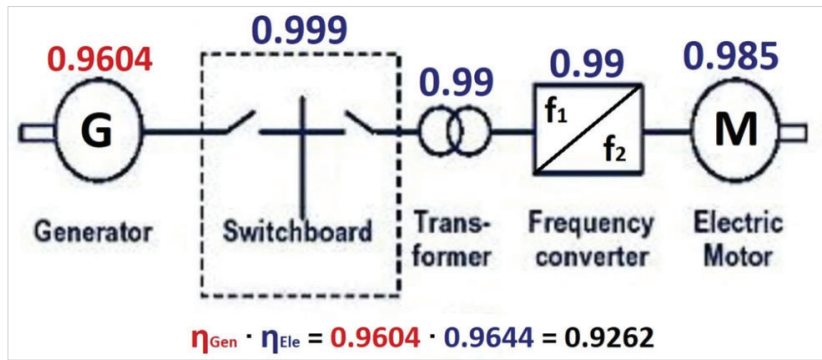

Figure 11 Efficiencies of the CODEL propulsion system

$$
\text { components }
$$

Slika 11. Učinkovitosti komponenti CODEL porivnog sustava Source: Own study on basis [14]

CODED-CRP propulsion system:

$$
\mathrm{P}_{\mathrm{B}_{\text {CODED-CRP }}}=\frac{\mathrm{P}_{\mathrm{E}_{\text {CODED-CRP }}}}{\eta_{\mathrm{T}_{\text {CODED-CRP }}}}=\frac{\mathrm{P}_{\mathrm{E}_{\text {CODED-CRP }}}}{\frac{\eta_{\mathrm{T}_{\text {mech }}} \cdot \mathrm{P}_{\mathrm{B}_{\text {mech }}}+\eta_{\mathrm{T}_{\mathrm{el}}} \cdot \mathrm{P}_{\mathrm{B}_{\mathrm{el}}}}{\mathrm{P}_{\mathrm{B}_{\text {mech }}}+\mathrm{P}_{\mathrm{B}_{\mathrm{el}}}}}
$$

hence:

$$
\mathrm{P}_{\mathrm{B}_{\text {CODED-CRP }}}=\left(\frac{\mathrm{P}_{\mathrm{E}_{\text {mech }}}}{\eta_{\mathrm{T}_{\text {mech }}}}+\frac{\mathrm{P}_{\mathrm{E}_{\mathrm{el}}}}{\eta_{\mathrm{T}_{\mathrm{el}}}}\right)=\left(\mathrm{P}_{\mathrm{B}_{\text {mech }}}+\mathrm{P}_{\mathrm{B}_{\mathrm{el}}}\right)
$$

where:

$\eta_{\mathrm{T}_{\text {mech }}}=\eta_{\mathrm{T}_{\text {CODAD}}}$ - Total efficiency of diesel-mechanical part of CODED-CRP

$\eta_{\mathrm{T}_{\mathrm{el}}}=\eta_{\mathrm{T}_{\text {CODEL }}}$ - Total efficiency of diesel-electric part of CODED-CRP

The effective power of a hull equipped with CODED-CRP is split into components to estimate the efficiency and the required brake power, corresponding to the diesel-mechanical and the diesel-electric parts of the system, which have different parameters. According to Wärtsilä [15], to ensure the highest energy efficiency, the power should be divided equally between the controllable pitch propeller and fixed pitch propeller. Due to the impossibility of free adjustment of the required power and rotational speed of the low-speed synchronous motor of the Azipod, however, the maximum benefits are not always achievable. Aiming to approach a value of $50 \%$ of expected propulsion power and to increase the rotational speed and reduce the propeller diameter by $20 \%$ relative to the controllable pitch propeller to avoid cavitation, the Azipod XC1800, with a rated brake power of $13,500 \mathrm{~kW}$ and a rotational speed of $195 \mathrm{rpm}$, was selected [21]. Multiplying the rated brake power of the Azipod by the product of the efficiencies in this section of the propulsion system, according to equation (6), a correct value of effective power was obtained. By subtracting the latter value from the total value, it was possible to obtain a correct value of effective power for the diesel-mechanical part $\mathrm{P}_{\mathrm{E}_{\text {mech }}}$ (9) and to determine the power split according to formulae (7) and (8).

$$
\mathrm{P}_{\mathrm{E}_{\text {mech }}}=\mathrm{P}_{\mathrm{E}_{\text {CODED-CRP }}}-\mathrm{P}_{\mathrm{E}_{\text {el }}}
$$

Major geometric and operational parameters of all propellers are shown in Table 4: 
Table 4 Parameters of the propellers

Tablica 4. Parametri propelera

\begin{tabular}{|c|c|c|c|c|c|c|c|}
\hline & & & & CODAD & \multicolumn{2}{|c|}{ CODED-CRP } & CODEL \\
\hline No. & Parameter & Symbol & Unit & \multicolumn{4}{|c|}{ Value } \\
\hline 1. & Quantity & - & - & 2 & 1 & 1 & 2 \\
\hline 2. & Propeller type & - & - & \multicolumn{2}{|c|}{ Controllable pitch (CPP) } & \multicolumn{2}{|c|}{ Fixed pitch (FPP) } \\
\hline 3. & Propeller blades geometry & - & - & \multicolumn{4}{|c|}{ B-Wageningen series } \\
\hline 4. & Number of blades & Z & - & 4 & 4 & 5 & 4 \\
\hline 5. & $\begin{array}{l}\text { Number of service revolutions } \\
\text { (corresponding to engine Nominal } \\
\text { Continuous Rating) }\end{array}$ & $\mathrm{n}_{\mathrm{NCR}}$ & rpm & 115 & 105 & 188 & 115 \\
\hline 6. & Diameter & D & $\mathrm{m}$ & 5.25 & 5.25 & 4.2 & 5.25 \\
\hline 7. & Propeller pitch ratio & $\frac{P}{D}$ & - & 1.4 & 1.4 & 1.1 & 1.4 \\
\hline 8. & Expanded area ratio & $\frac{A_{E}}{A_{0}}$ & - & 0.85 & 1.05 & 0.75 & 0.85 \\
\hline
\end{tabular}

Source: Own study

Calculated energy indicators of analysed propulsion systems were discussed below and then shown in Table 5. Hull efficiency is a ratio between effective and thrust power which the propeller delivers to the water, determined as a quotient of thrust deduction coefficient and wake fraction coefficient $[9,16,22]$ :

where:

$$
\eta_{\mathrm{H}}=\frac{1-\mathrm{t}}{1-\mathrm{w}}
$$

$\mathrm{t}$ - Thrust deduction coefficient

w - Wake fraction coefficient

Open water efficiency is a ratio of the thrust power to the power absorbed by the propeller operating without a hull attached, i.e. in open water, determined in relation to thrust loading coefficient $[9,16,22]$ :

where:

$$
\eta_{\mathrm{O}}=\frac{2}{1+\sqrt{\mathrm{C}_{\mathrm{Th}}+1}} \cdot 0.81-0.014 \cdot \mathrm{C}_{\mathrm{Th}}
$$

$\mathrm{C}_{\text {Th }}$ - Thrust loading coefficient

Relative rotative efficiency describes a ratio between efficiency of the propeller behind hull and in open water conditions. Value of this parameter was obtained from formula for twin-screw vessels $[9,16,22]$ :

$\eta_{R}=0.9737+0.111 \cdot\left[C_{P}-0.0225 \cdot\left(7 \cdot \sqrt{0.68-C_{B}}\right)\right]-0.06325 \cdot \frac{P}{D}$

where:

$C_{p}$ - Prismatic coefficient (Table 1)

$C_{B}$ - Block coefficient (Table 1)

$\frac{\mathrm{P}}{\mathrm{D}}$ - Propeller pitch ratio (Table 3 )

Shaft line and gearbox efficiency were taken as an average constant values of these parameters for twin-screw vessels. Generator and electrical energy transmission efficiency (Figure 9) are values declared by the manufacturers [14, 23, 24].

Total efficiency of diesel-mechanical and diesel-electric parts were obtained according to (5) and (6), which are equivalent to CODAD and CODEL total efficiency. However, CODED-CRP total efficiency was considered to be a weighted average of the efficiency of both mentioned parts according to (7).

Main engines and diesel generating sets were selected for the capacity to ensure the required brake power, minimise fuel

Table 5 Energy indicators of analysed propulsion systems

\begin{tabular}{|c|c|c|c|c|c|c|}
\hline & & & & \multirow{3}{*}{\multicolumn{2}{|c|}{$\begin{array}{c}\text { CODED - CRP } \\
\text { Value }\end{array}$}} & \multirow{3}{*}{ CODEL } \\
\hline & & & & & & \\
\hline No. & Parameter (efficiency) & Symbol & Unit & & & \\
\hline 1. & Hull & $\eta_{H}$ & - & 0.9837 & 1.0745 & 0.9837 \\
\hline 2. & Open water (CPP) & $\eta_{0}$ & \multirow{5}{*}{-} & 0.7315 & 0.7005 & \multirow{5}{*}{-} \\
\hline 3. & Relative-rotative (CPP) & $\eta_{R}$ & & 0.945 & 0.9706 & \\
\hline 4. & Shaft line & $\eta_{s}$ & & & 85 & \\
\hline 5. & Gearbox & $\eta_{G}$ & & & 97 & \\
\hline 6. & Total of diesel-mechanical part & $\eta_{\mathrm{T}_{\text {mech }}}$ & & 0.6498 & 0.6979 & \\
\hline 7. & Open water (Azipod FPP) & $\eta_{0}$ & \multirow{5}{*}{-} & \multirow{5}{*}{-} & 0.7077 & 0.7465 \\
\hline 8. & Relative-rotative (Azipod FPP) & $\eta_{R}$ & & & 1.0375 & 0.945 \\
\hline 9. & Electrical energy transmission & $\eta_{\text {Ele }}$ & & & \multicolumn{2}{|c|}{0.9644} \\
\hline 10. & Generator & $\eta_{\mathrm{Gen}}$ & & & \multicolumn{2}{|c|}{0.9604} \\
\hline 11. & Total of diesel-electric part & $\eta_{\mathrm{T}} \mathrm{el}$ & & & 0.7307 & 0.6434 \\
\hline 12. & Total of propulsion system & $\eta_{T}$ & - & $\begin{array}{c}0.6498 \\
100 \%\end{array}$ & $\begin{array}{c}0.7107 \\
109.37 \%\end{array}$ & $\begin{array}{c}0.6434 \\
99.02 \%\end{array}$ \\
\hline 13. & Service brake power (Nominal Continuous Rating) & $\mathbf{P}_{\mathbf{B}_{\mathrm{NCR}}}$ & kW & 34,056 & 30,310 & 34,400 \\
\hline 14. & Power split & $\frac{\mathbf{P}_{\mathbf{B}_{\text {mech }}}}{\mathbf{P}_{\mathbf{B}_{\text {el }}}}$ & - & - & $\frac{0.5675}{0.4325}$ & - \\
\hline
\end{tabular}
Tablica 5. Energetski indikatori analiziranih porivnih sustava 
oil consumption and, in the case of the controllable pitch propeller powered by the CODAD and linear $(\mathrm{L})$ cylinder alignment, reduce the volume of engine rooms. Selected models and the values of specific fuel oil consumption (SFOC) under service load in ISO ambient conditions are presented in Table 6 [23, 24].

\section{RESULTS AND DISCUSSION / Rezultati i rasprava}

Comparative analysis of operational efficiency of proposed variants of large RoPax propulsion systems was carried out using the selected energy and economic indicators provided in Table 7 which were referred to the standard CODAD propulsion system [8].

Table 6 Selected main engines and diesel generating sets

Tablica 6. Odabrani glavni motori i dizel generatori

\begin{tabular}{|c|c|c|c|c|c|c|c|c|c|c|c|}
\hline No. & Engine & $\begin{array}{c}\mathrm{P}_{\mathrm{B}_{\mathrm{NMCR}}} \\
\mathrm{kW}\end{array}$ & $\begin{array}{c}N_{\text {NMCR }} \\
\text { rpm }\end{array}$ & $\begin{array}{c}\mathrm{P}_{\mathrm{B}_{\mathrm{MCR}}} \\
\mathrm{kW}\end{array}$ & $\begin{array}{l}N_{\text {MCR }} \\
\text { rpm }\end{array}$ & $\begin{array}{c}\mathrm{P}_{\mathrm{B}_{\mathrm{NCR}}} \\
\mathrm{kW}\end{array}$ & $\begin{array}{l}N_{\mathrm{NCR}} \\
\mathrm{rpm}\end{array}$ & $\begin{array}{c}\text { SFOC }_{\mathrm{NCR}} \\
\frac{\mathrm{g}}{\mathrm{kWh}}\end{array}$ & Quantity & System & Application \\
\hline 1. & \multirow{2}{*}{ Wärtsilä 8L46F } & \multirow{2}{*}{9,600} & \multirow{2}{*}{600} & 9,460 & 597 & 8,514 & 576 & 173.95 & 4 & CODAD & CPP drive \\
\hline 2. & & & & 9,555 & 599 & 8,600 & 578 & 174.15 & 2 & \multirow{2}{*}{ CODED-CRP } & 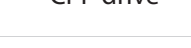 \\
\hline 3. & Wärtsilä 12V31 & 7,320 & 750 & 7,283 & 749 & 6,555 & 723 & 167.96 & 2 & & Generator drive \\
\hline 4. & Wärtsilä 16V31 & 9,760 & 750 & 8,600 & 719 & 7,740 & 694 & 169.95 & 4 & CODEL & Generator drive \\
\hline
\end{tabular}

Source: Own study on basis $[23,24]$

Table 7 Major energy and economic indicators Tablica 7. Glavni energetski i ekonomski pokazatelji

\begin{tabular}{|c|c|c|c|c|c|c|}
\hline & & & & CODAD & CODED - CRP & CODEL \\
\hline No. & Parameter & Symbol & Unit & \multicolumn{3}{|c|}{ Value } \\
\hline 1. & Total efficiency of propulsion system & $\eta_{\mathrm{T}}$ & - & $\begin{array}{c}0.6498 \\
100 \%\end{array}$ & $\begin{array}{c}0.7107 \\
109.37 \%\end{array}$ & $\begin{array}{l}0.6434 \\
99.02 \%\end{array}$ \\
\hline 2. & $\begin{array}{l}\text { Service brake power } \\
\text { (Nominal Continuous Rating) }\end{array}$ & $\mathrm{P}_{\mathrm{B}_{\mathrm{NCR}}}$ & \multirow{3}{*}{ kW } & $\begin{array}{c}34,056 \\
100 \%\end{array}$ & $\begin{array}{c}30,310 \\
89 \%\end{array}$ & $\begin{array}{c}34,400 \\
101.01 \%\end{array}$ \\
\hline 3. & $\begin{array}{l}\text { Maximum continuous power (Maximum } \\
\text { Continuous Rating) }\end{array}$ & $\mathrm{P}_{\mathrm{B}_{\mathrm{MCR}}}$ & & $\begin{array}{c}37,840 \\
100 \%\end{array}$ & $\begin{array}{c}33,676 \\
89 \%\end{array}$ & $\begin{array}{c}38,222 \\
101.01 \%\end{array}$ \\
\hline 4. & $\begin{array}{l}\text { Total installed power (Nominal Maximum } \\
\text { Continuous Rating) }\end{array}$ & $\sum \mathrm{P}_{\mathrm{B}_{\mathrm{NMCR}}}$ & & $\begin{array}{c}38,400 \\
100 \%\end{array}$ & $\begin{array}{l}33,840 \\
88.12 \%\end{array}$ & $\begin{array}{c}38,720 \\
100.83 \%\end{array}$ \\
\hline 5. & Specific fuel oil consumption & $\mathrm{SFOC}_{\mathrm{NCR}}$ & $\frac{\mathrm{g}}{\mathrm{kWh}}$ & $\begin{array}{c}173.95 \\
100 \%\end{array}$ & $\begin{array}{l}171.47 \\
98.57 \%\end{array}$ & $\begin{array}{l}170.05 \\
97.76 \%\end{array}$ \\
\hline 6. & Daily fuel oil consumption & $\mathrm{DFOC}_{\mathrm{NCR}}$ & $\frac{\mathrm{t}}{\mathrm{day}}$ & $\begin{array}{c}142.18 \\
100 \%\end{array}$ & $\begin{array}{l}124.73 \\
87.73 \%\end{array}$ & $\begin{array}{l}140.37 \\
98.73 \%\end{array}$ \\
\hline 7. & $\begin{array}{l}\text { Annualy fuel oil consumption (operation } \\
\text { time: } 2 / 3 \text { of year) }\end{array}$ & $\mathrm{AFOC}_{\mathrm{NCR}}$ & $\frac{t}{\text { year }}$ & $\begin{array}{c}34,597.1 \\
100 \%\end{array}$ & $\begin{array}{l}30,350.9 \\
87.73 \%\end{array}$ & $\begin{array}{c}34,156.7 \\
98.73 \%\end{array}$ \\
\hline 8. & Daily fuel oil costs & \multirow[t]{2}{*}{ - } & $\frac{\text { USD }}{\text { day }}$ & $\begin{array}{c}78,199 \\
100 \%\end{array}$ & $\begin{array}{l}68,601.5 \\
87.73 \%\end{array}$ & $\begin{array}{c}77,203.5 \\
98.73 \%\end{array}$ \\
\hline 9. & $\begin{array}{l}\text { Annualy fuel oil costs (operation time: } 2 / 3 \\
\text { of year) }\end{array}$ & & $\frac{\text { USD }}{\text { year }}$ & $\begin{array}{c}19,028,423 \\
100 \%\end{array}$ & $\begin{array}{c}16,693,032 \\
87.73 \%\end{array}$ & $\begin{array}{c}18,786,185 \\
98.73 \%\end{array}$ \\
\hline
\end{tabular}

Source: Own study

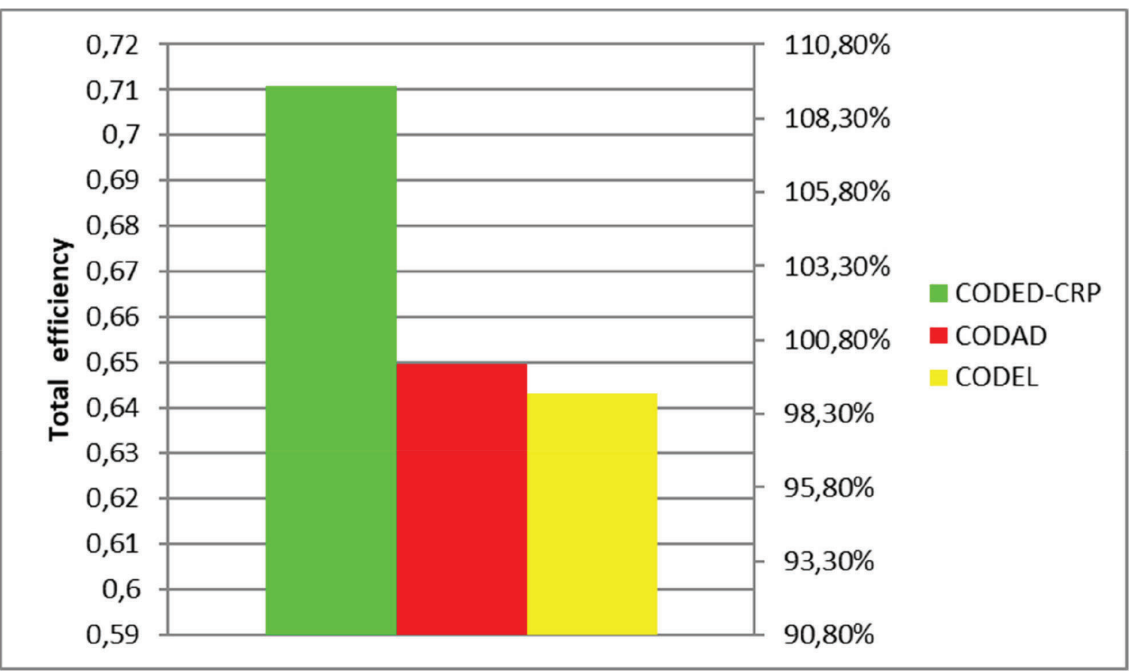

Figure 12 Total efficiency of analysed propulsion systems on their service load compared to CODAD. Its total efficiency 0.6498 is a $100 \%$ reference point to others

Slika 12. Ukupna učinkovitost analiziranih porivnih sustava na radnom opterećenju u usporedbi s CODAD. Njihova ukupna učinkovitost 0.6498 je $100 \%$ referentna točka drugima 
On the basis of a comparison of the results of calculations given in Table 6 and shown in Figure 12, it was concluded that a vessel equipped with the CODED-CRP propulsion system has a total propulsive efficiency higher by 6.09 p.p. (9.37\%) than the efficiency of CODAD, assuming a value of 0.7107 comparable to that of the direct-drive propulsion system with low-speed engine and fixed pitch propeller. Moreover, both the diesel-mechanical section and the diesel-electric section of the CODED-CRP system have total efficiencies higher than the efficiency of CODAD (Table 4), respectively by 4.81 p.p. (7.4\%) and 8.09 p.p. (12.45\%), as a result of a considerably higher value of the product of the hull efficiency and relative-rotative efficiency (Table 4), which easily offsets the lower efficiency of the propellers and losses in the generation and transmission of electrical energy. This is due to a more streamlined hull form very similar to the form used for single-propeller vessels - and the utilisation of part of the energy of the circular movement of water (generated by the controllable pitch propeller) by the Azipod's fixed pitch propeller. The CODEL system has total propulsive efficiency lower by 0.64 p.p. $(0.98 \%)$ than that of CODAD, yet it is still comparable. This results from the identical total resistance (Table 2) and losses in the generation and transmission of electrical energy that slightly exceed both the power transmission losses in the CODAD system and the gain from the fixed pitch propeller, which has slightly higher efficiency when installed in this system.

To sail with a service speed of 25 knots, CODED-CRP requires brake power of $30,310 \mathrm{~kW}$, which ensures savings up to 3,746 kW (11\%) relative to CODAD, with demand lower by $344 \mathrm{~kW}$ $(1.01 \%)$ than that of CODEL. These results, presented in Figure 13 , are obtained directly from the aforementioned differences of effective power and total efficiency of the propulsion systems.

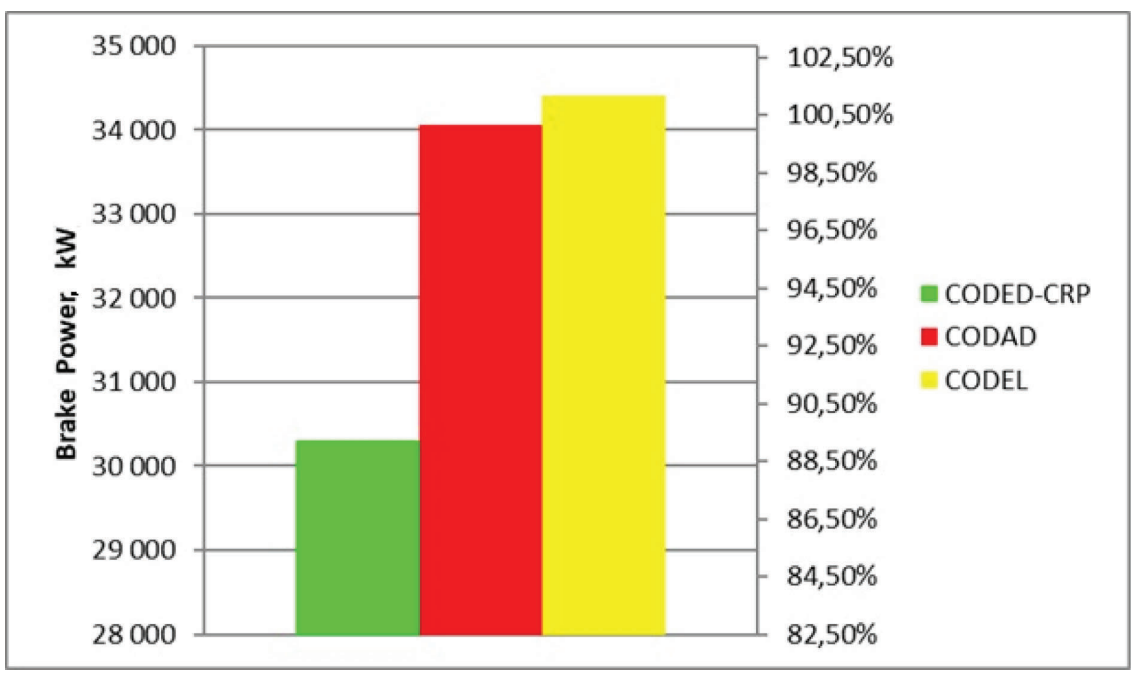

Figure 13 Service load brake power of analysed propulsion systems compared to CODAD. Its service brake power 34,056 kW is a $100 \%$ reference point to others

Slika 13. Efektivna snaga kočenja na radnom opterećenju analiziranih porivnih sustava u usporedbi s CODAD. Njihova radna efektivna snaga kočenja 34,056 kW JE $100 \%$ referentna točka drugima

Source: Own study

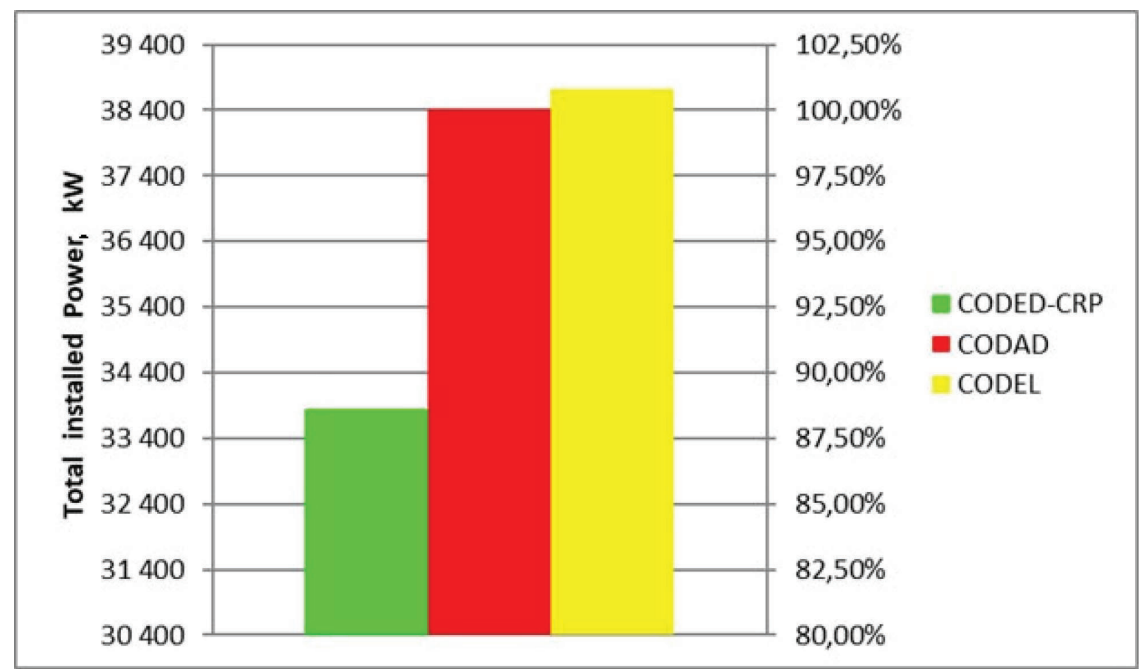

Figure 14 Total installed power of analysed propulsion systems compared to CODAD. Its total installed power $38,400 \mathrm{~kW}$ is a $100 \%$ reference point to others

Slika 14. Ukupna ugrađena snaga analiziranih porivnih sustava u usporedbi s CODAD. Njihova ugrađena snaga 38,400 kW JE $100 \%$ Source: Own study referentna točka drugima 
Total installed power is the sum of the rated powers of all engines driving the propellers and generators producing electrical energy for propulsive purposes. On the basis of a comparison of the data given in Table 6 (in accordance with Table 5) and in Figure 14, it was concluded that CODED-CRP requires lower installed power than CODAD by $4,560 \mathrm{~kW}$ (11.88\%) for operation under service load while maintaining the engine margin. CODEL requires diesel generating sets with a sum of rated powers equal to $38,720 \mathrm{~kW}$, exceeding the CODAD system's power by $320 \mathrm{~kW}(0.83 \%)$.

CODEL has the lowest specific fuel oil consumption for MGO (Marine Gas Oil) in ISO ambient conditions, amounting to $170.05 \mathrm{~g} / \mathrm{kWh}$, which is lower by $3.9 \mathrm{~g} / \mathrm{kWh}(2.24 \%)$ than the CODAD system's consumption (Figure 15). Such a low value was obtained using Wärtsilä V31 engines (Table 5) powering a synchronous generator. Their record-breaking minimum specific fuel oil consumption is equal to $167.7 \mathrm{~g} / \mathrm{kWh}$ at a rated load of $85 \%$. A pair of engines of this series is used similarly in the CODED-CRP system, for which this parameter, being the weighted average of the values for the diesel-mechanical and diesel-electric sections, amounts to $171.47 \mathrm{~g} / \mathrm{kWh}$. This ensures savings up to $2.48 \mathrm{~g} / \mathrm{kWh}(1.63 \%)$ relative to the CODAD system, which is based entirely on Wärtsilä 8L46F engines with lower energy efficiency.

Daily and annual fuel oil consumption are the products of the specific fuel oil consumption and attained brake power with time, expressed as a number of hours or days. In the case of the second indicator it was assumed that the vessel is used for $2 / 3$ of the year under service load. The CODED-CRP system consumes $124.73 \mathrm{t} /$ day (Figure 16) and 30,350.9 t/year of fuel, which allows $17.45 \mathrm{t} /$ day and 4,246.2 t/year (12.27\%) to be saved relative to the CODAD system. These differences arise from lower values of specific fuel oil consumption and service brake power. In the CODEL system the savings result only from

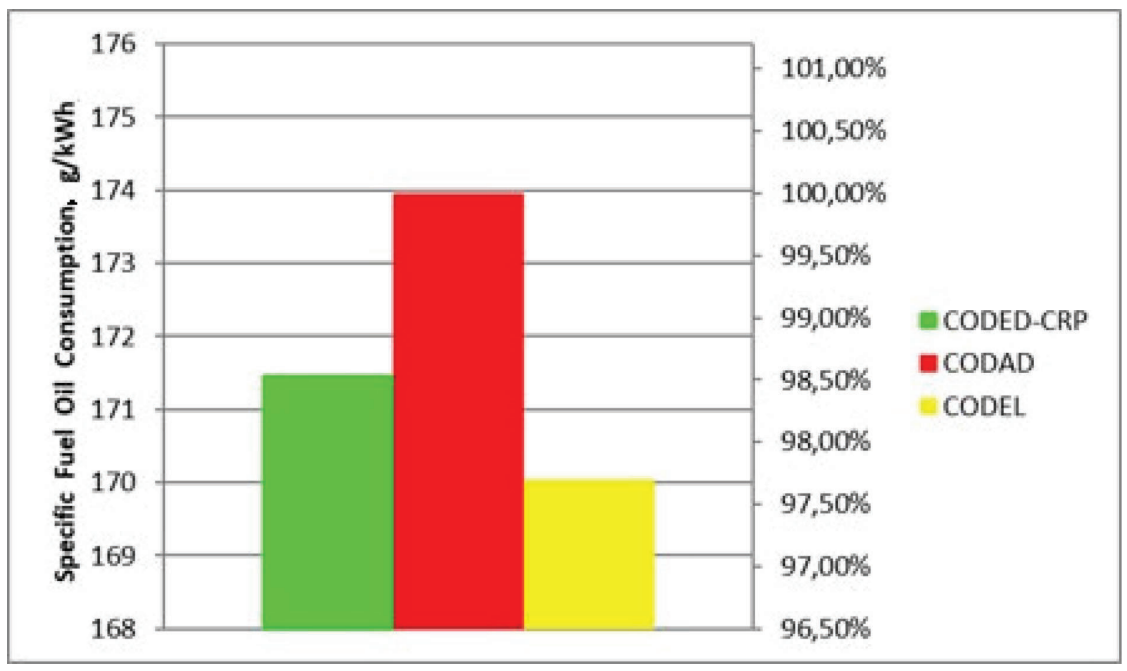

Figure 15 Specific fuel oil consumption of analysed propulsion systems compared to CODAD. Its specific fuel oil consumption $173.95 \mathrm{~g} / \mathrm{kWh}$ is a $100 \%$ reference point to others

Slika 15. Specifična potrošnja goriva analiziranih porivnih sustava u usporedbi s CODAD. Njihova specifična potrošnja goriva $173.95 \mathrm{~g} /$ Source: Own study kWh je $100 \%$ referentna točka drugima

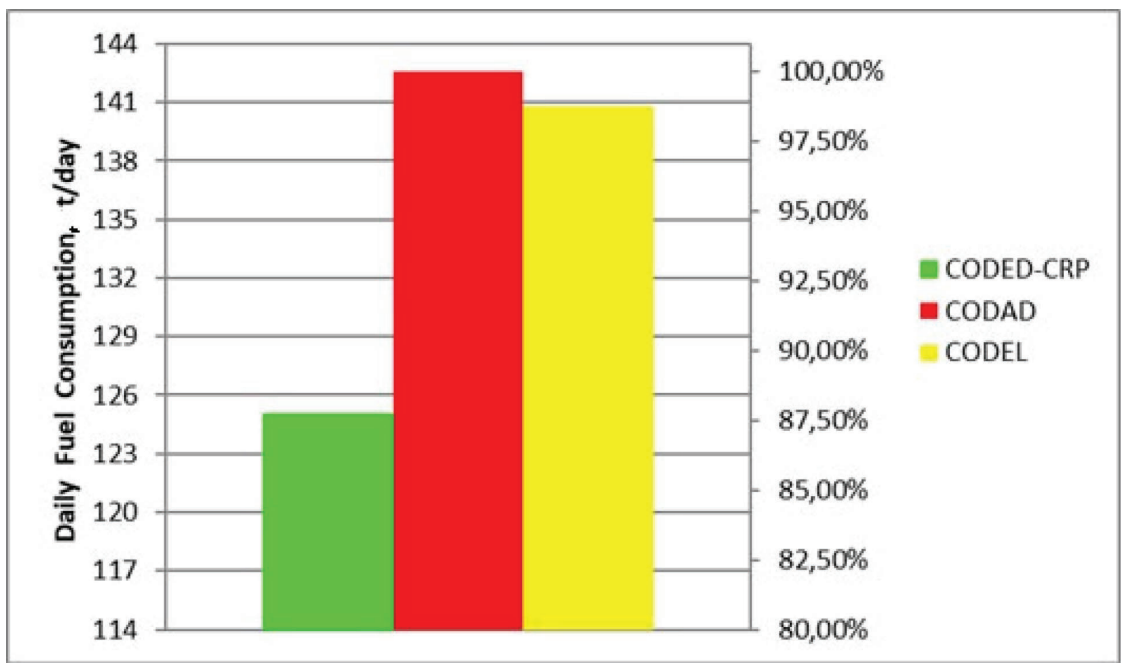

Figure 16 Daily fuel oil consumption of analysed propulsion systems compared to CODAD. Its daily fuel oil consumption $142.18 \mathrm{t} /$ day is a $100 \%$ reference point to others

Slika 16. Dnevna potrošnja goriva analiziranih porivnih sustava u usporedbi s CODAD. Njihova dnevna potrošnja goriva $142.18 \mathrm{t} /$ day je Source: Own study $100 \%$ referentna točka drugima 
the first of the aforementioned indicators, which causes the system to consume $1.81 \mathrm{t} /$ day and $440.4 \mathrm{t} /$ year (1.27\%) less fuel oil than CODAD.

The average price of MGO (Marine Gas Oil) on European markets in 2019, amounting to 550 USD/t [25] was used to compare costs of fuel oil consumption. Both alternative propulsion systems allow the saving of some part of the amount corresponding to CODAD's fuel oil consumption per hour, which results from the fact that they are its multiples. The CODED-CRP system generates savings up to 9,597.5 USD/day and 2,335,391 USD/year. The CODEL system's savings are nearly tenfold lower, at 995.5 USD/day and 242,238 USD/year.

\section{CONCLUSIONS / Zaključci}

The calculation results presented in Table 7 indicate that the brake power of a large RoPax with CODED-CRP required for operation at service speed will be lower by $11 \%$ than for the same vessel equipped with CODAD, due to lower total resistance (by $2.7 \%$ ) and higher total propulsive efficiency of the propulsion system (by $9.73 \%$ ). Therefore, total installed power will also be lower (by $11.88 \%$ ), as will the consumption and costs of fuel oil (by 12.27\%).

What is more, a large RoPax vessel equipped with CODEDCRP also offers better manoeuvrability (the entire Azipod thruster power may be used for steering) and greater capacity to maintain higher efficiencies of the propulsion system in the part-load range (the electric propulsion is better adapted to load variation, and generators producing electrical energy for the Azipod may also replace the auxiliary propulsion to avoid inefficient operation in a low load range).

Nevertheless, the costs of construction of a ferry equipped with the CODED-CRP system are significantly higher (especially due to the purchase and installation of the Azipod thruster) than the costs of the standard CODAD system, but this type of main propulsion system entails a series of benefits, presented in Table 1, which enable investment expenditure to be recovered in the course of long-term service. On this basis it is concluded that the CODED-CRP system, which combines the advantages of CODAD and CODEL, may be the best solution both for ferries serving long routes with a large proportion of operation time under service load, and for ferries serving short routes with a negligible proportion of operation time under service load.

The CODEL propulsion system is selected only for ferries serving short routes running mainly under reduced load. Generating low savings under service load, it cannot enable increased investment expenditure to be recovered over a standard 20-year ferry service period on the long routes dominated by CODAD vessels, which still prevail in current order portfolios. It should be expected, however, that the use of CODED-CRP in newly built vessels will become more frequent with the development and growing popularity of hybrid propulsion systems as a consequence of increasingly restrictive emission limits for harmful substances.

\section{REFERENCES / Literatura}

[1] Urbanyi - Popiołek, I. (2015). Kierunki rozwoju tonażu na światowym rynku żeglugi promowej, Studia i Materiały Instytutu Transportu i Handlu Morskiego $12 / 2015$

[2] Shippax Information. (2019). Shippax Market 19. Halmstad

[3] Adamkiewicz, A. and Jarzęcki, Ł. (2009) Comparative analysis of operational properties of RoPax ship types, Maintenance and Reliability, Vol. 2

[4] Bazari, Z. (2020). MARPOL Annex VI Chapter 4 - Energy efficiency regulations, National Workshop on Ratification and Implementation of MARPOL Annex VI for Egypt, Available at: https://www.rempec.org/en/knowledge-centre/ online-catalogue/5-zb-103-marpol-annex-vi-chapter-4-final.pdf (Accessed: 19 December 2020)

[5] Deltamarin (2020). Future fuel options and emission control, Available at: https://deltamarin.com/current-challenges/future-fuel-options-and-emi ssion-control/ (Accessed: 19 December 2020)

[6] Clausen, N.B. (2015). Tier III NOX emission reduction technologies EGR and SCR, Available at: https://marine.man-es.com/docs/librariesprovider6/ marketing-publications/japanese-seminar-2018-english/02-meeting-eedifuture-ghg-challenges.pdf (Accessed: 19 December 2020)

[7] Levander O. (2002). Advanced machinery with CRP propulsion for Fast RoPax vessels, The Motorship Marine Conference

[8] Korlak, P. (2019). Analiza efektywności wykorzystania układu napędowego promu RoPax o pojemności brutto 46000 , Praca dyplomowa magisterska, Wydział Mechaniczno-Elektryczny, Akademia Marynarki Wojennej im. Bohaterów Westerplatte, Gdynia

[9] Babicz, J. (2017). Wärtsilä Encyclopedia of Ship Technology, Issue 2, Wärtsilä Corporation, Helsinki

[10] Hämäläinen, R. and Van Heerd, J. (2013). Energy saving possibilities in twin or triple propeller cruise liners, Third International Symposium on Marine Propulsors smp'13, Launceston, Tasmania, Australia. Available at: https://www.marinepropulsors.com/ proceedings/2013/2A.1.pdf (Accessed: 19 December 2020)

[11] Giernalczyk, M. and Górski, Z. (2016). Siłownie okrętowe cz. I - Podstawy napędu i energetyki okrętowej, Wydawnictwo Akademii Morskiej w Gdyni, Gdynia

[12] DNV - GL. (2019). Vessel register for DNV - GL. Available at: http:/ vesselregister.dnv-gl.com/ (Accessed: 19 December 2020)

[13] MAN Energy Solutions. (2020). MAN Re-Enters Finnish Market with Baltic Order - MAN 51/60DF engines running on LNG to power innovative Estonian shuttle ferry built by RMC, Press release, Copenhagen. Available at: https://man-es. com/docs/default-source/press-releases-new/20200311_man_pr-tallinkfinland-5160df_en.pdf?sfvrsn=d9e12983_2 (Accessed: 19 December 2020)

[14] Łosiewicz, Z. and Łukasik, Z. (2017). Zespół napędowy spalinowo-elektryczny na statkach offshore - założenia projektowe w aspekcie zdatności do wykonywania zadania eksploatacyjnego i bezpieczeństwa żeglugi, Autobusy, Vol. 6

[15] Simonsen C. D., (2016). Technical report - low emission RoPax ferry study, Available at: https://www.dendanskemaritimefond.dk/wp-content/uploads /2016/02/GSF_Low_emission_ROPAX_ferry_tehnical_report.pdf (Accessed: 19 December 2020)

[16] Hudson, D. A., Molland, A. F. and Turnock S. R. (2011). Ship resistance and propulsion, Cambridge University Press, Cambridge, https://doi.org/10.1017/ CBO9780511974113

[17] Holtrop, J., Mennen, G. G. J., (1982). An approximate power prediction method, International Shipbuilding Progress, Vol. 29, Nr 335, https://doi. org/10.3233/ISP-1982-2933501

[18] Fincantieri (2020). Available at: https://www.fincantieri.com/globalassets/ prodotti-servizi/traghetti/traghetti-finnstar.pdf (Accessed: 19 December 2020)

[19] Kanar, J. (2009). Półempiryczna metoda prognozowania właściwości napędowych statków z napędów wielopodowym, Rozprawa doktorska, Wydział Oceanotechniki i Okrętownictwa, Politechnika Gdańska, Gdańsk

[20] Leduc, M. (2002). Available at: http://www.dieselduck.info/machine/02\%20 propulsion/shafting/index.htm (Accessed: 19 December 2020)

[21] ABB Marine. (2010). Azipod Product Platform Selection Guide, Helsinki. Available at: https://library.e.abb.com/public/1b13ae404001bd3ec125778 a004300ac/ABB\%20-\%20Azipod\%20Selection\%20Guide.pdf (Accessed: 19 December 2020)

[22] Molland, A. F. (2015). The maritime engineering reference book, Elsevier Butterworth-Heinemann, Oxford

[23] Wärtsilä Marine. (2019). Wärtsilä 31F Product Guide, Vaasa. Available at: https://www.wartsila.com/docs/default-source/product-files/engines/ ms-engine/product-guide-o-e-w31.pdf?utm source=engines\&utm medium=dieselengines\&utm_term=w31\&utm_content=productguide\&utm _ campaign=msleadscoring (Accessed: 19 December 2020)

[24] Wärtsilä Marine. (2020). Wärtsilä 46F Product Guide, Vaasa. Available at: https://www.wartsila.com/docs/default-source/product-files/engines/ ms-engine/product-guide-o-e-w46f.pdf?utm source=engines\&utm medium =dieselengines\&utm_term $=\mathrm{w} 46 \mathrm{f} \& u t \mathrm{tm} \_$content=productguide\&utm campaign=msleadscoring (Accessed: 19 December 2020)

[25] Ship and Bunker. (2020). EMEA Bunker Prices. Available at: http://shipandbunker.com/prices/emea (Accessed: 19 December 2020) 